\title{
The Economic Impact Of Water Resource: Broken Bow Lake In Mccurtain County In Southeastern Oklahoma
}

\author{
Matthew Nga Uwakonye, Grambling State University, USA \\ Gbolahan S. Osho, Prairie View A\&M University, USA \\ Emmanuel I.S. Ajuzie, Lincoln University, USA
}

\begin{abstract}
Oklahoma has had water problems in the past, when most cities and towns relied mostly on wells pumping water to irrigate their agricultural lands and to provide water for municipal and industrial purposes. One of the fundamental elements of the social accounting method, especially the macroeconomic analysis and planning in the developed market economies, is the Social Accounting Matrix (SAM). The Social Accounting Matrix could be defined as a system of accounts integrated in the form of matrix, consistently including data on production and income generation on one hand, and on the revenues and expenditures of various institutional groups and classes in society on the other. The present study presents a frame work for using a Social Accounting matrix (SAM) technique to analyze the economic impacts of Broken Bow Lake in McCurtain County. The SAM has been used in developing countries to explore the interaction between macro-policy and structure adjustment. Using multiplier analysis, results of the present study can be used to illustrate how this frame work can capture the essential structural features of McCurtain County and sort out the direct and indirect links through which macro-shocks affect the systems (Sherman Robinson).
\end{abstract}

Keywords: SAM, Social Accounting Matrix, Input-Output Matrix, Production and Demand Functions McCurtain County, Broken Bow Lake, Agricultural Commodities, Soil Conservation Service, and Government Investment

\section{INTRODUCTION}

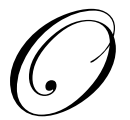

klahoma has had water problems in the past, when most cities and towns relied mostly on wells pumping water to irrigate their agricultural lands and to provide water for municipal and industrial purposes. The water problem in Oklahoma was alleviated somewhat when the U.S. Army Corps of Engineers, the State of Oklahoma, the Soil Conservation Service of the U.S. Department of Agriculture, and the Bureau of Reclamation of the U.S. Department of Interior began construction of impoundments in Oklahoma.

Few economic impact studies have been done on the multiple purpose uses of water resource development projects in Oklahoma. Chang and Badger analyzed some of the navigation impacts and recreation impacts of the McClellan -Kerr Arkansas River Navigation System in the 1970's. Most of the economic impacts of recreation along the McClellan-Kerr Navigation System in both Oklahoma and Arkansas were analyzed by Schreiner, Willet, Badger, and Presley. However, lager number of recreationists is using recreational facilities at other Corps lakes, at Bureau of Reclamations Projects and at Soil Conservation Service (SCS) detention structures. Essentially, no analysis has been done to estimate this economic impact, or the impacts from other purposes of the projects.

Schreiner, Chantaworn, and Badger analyzed the need for intensive planning for investment in multiple purpose water resource projects. Warner, Badger and Lage analyzed multiple purpose economic impacts of Lake Tenkiller, a Corps of Engineers lake, in 2000. However, no recent studies on economic impacts of these lakes have been accomplished. 
The present study presents a framework for using a Social Accounting matrix (SAM) technique to analyze the economic impacts of Broken Bow Lake in McCurtain County. The SAM has been used in developing countries to explore the interaction between macro-policy and structure adjustment. Using multiplier analysis, results of the present study can be used to illustrate how this framework can capture the essential structural features of McCurtain County and sort out the direct and indirect links through which macro-shocks affect the systems (Sherman Robinson).

One of the fundamental elements of the social accounting method, especially the macroeconomic analysis and planning in the developed market economies, is the Social Accounting Matrix (SAM). The Social Accounting Matrix could be defined as a system of accounts integrated in the form of a matrix, consistently including data on production and income generation on one hand and on the revenues and expenditures of various institutional groups and classes in society on the other. Hence, the Social Accounting Matrix provides detailed presentation of the input and output of factors of production generated in the domestic production, the distribution of income of factors of production of domestic and foreign origin to certain institutional groups in the society, expenditures of various classes and groups for consumption and investments, as well as their savings. Taking into account the fact that the Social Accounting Matrix includes all the stages of the production process, enabling presentation of the data at any level of disaggregation, it is clear that this statistical and documentary framework has greater potential from an analytical point of view, compared to other systems of economic data, such as national accounts and input-output tables.

The preparation and application of Social Accounting Matrix within the US system of national accounts were connected with the growing discontent from the results of the growth policies, especially in developing countries, so SAM has two main objectives:

1. To enable synthesizing and organization of information on the economic and social structure of the county.

2. To enable analytical and documentary basis for preparation of a macroeconomic model of analysis of the functioning of the economy and anticipate the effects from the implementation of macroeconomic policy measures.

Social Accounting Matrix successfully combines indicators of growth, allocation of income and poverty in one coherent framework. By including elements of input-output tables, national accounts and other databases, Social Accounting Matrix provides a complex, quantitative image suitable for macroeconomic analysis and planning.

\section{STRUCTURE OF SOCIAL ACCOUNTING MATRIX}

A Social Accounting Matrix (SAM) is a table, in matrix form, that shows transactions between sectors (accounts) within an economy. Each row of the matrix records the details of receipts by each account and column entries record the corresponding expenditures. For instance, each identified agent (household account, government account, and production account, etc.) in the economy is assigned a row and column. By accounting convention, total receipts must be equal to total outlay, and each row sum in the matrix is equal to the corresponding column sum. However, this examines the strength of disaggregation and number of rows and columns in the SAM, respectively. The essential components of the basic social accounting matrix are shown in Table 1. 
Table 1: A Basic Social Accounting Matrix (SAM)

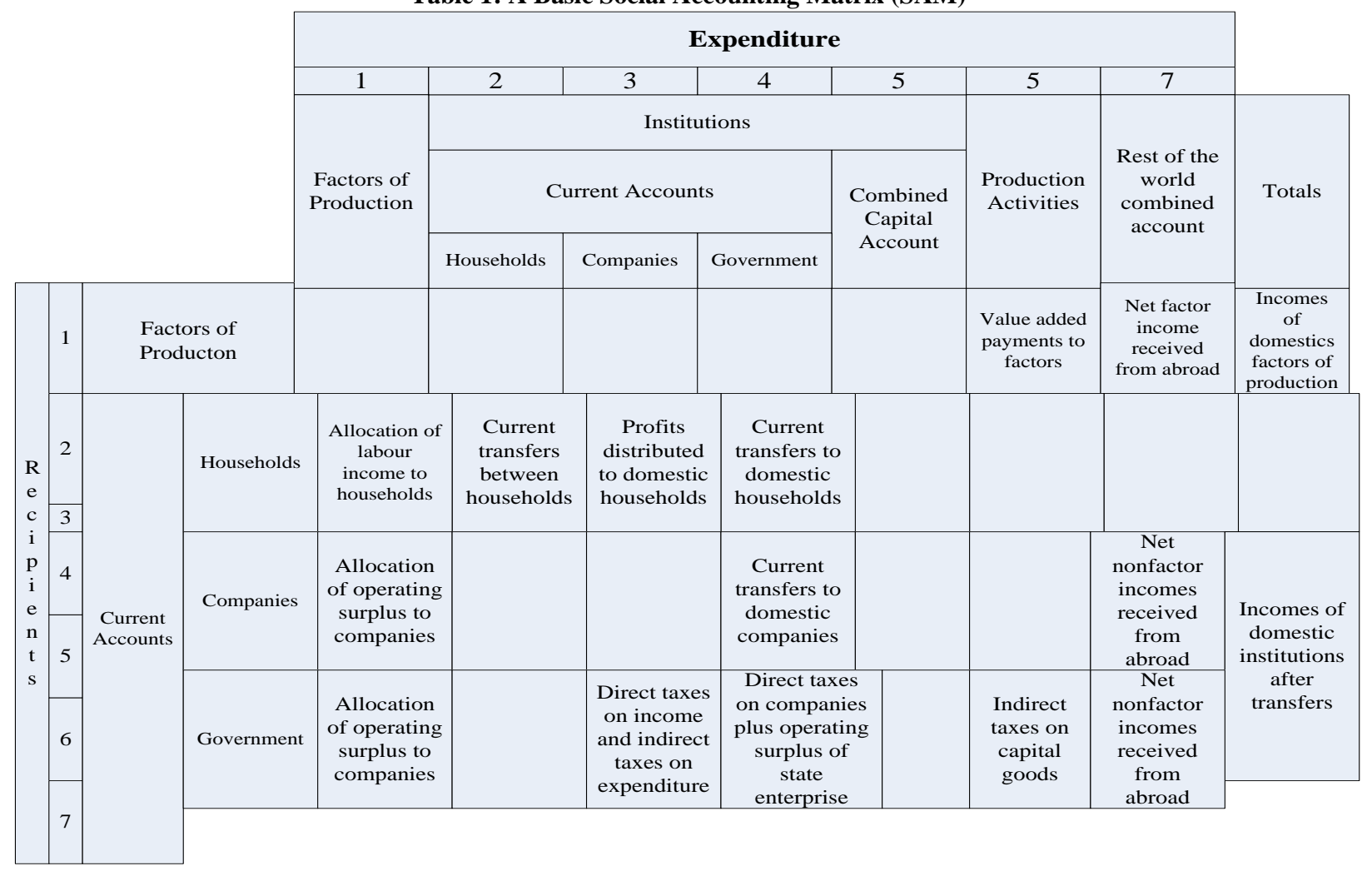

A SAM is a table, in matrix form, where corresponding columns and rows show the expenditure and receipt accounts of economic agents. Note $V_{i, j}$ is expenditure from column account $j$ to row account $i$ as a receipt. Thus, a SAM equals:

$\mathrm{U}_{\mathrm{i}}=\sum_{\mathrm{j}} \mathrm{V}_{\mathrm{i}, \mathrm{j}}=\sum_{\mathrm{j}} \mathrm{V}_{\mathrm{j}, \mathrm{i}}$

$\mathrm{U}_{\mathrm{i}}$ is total receipts and expenditures of account i.

$a_{i, j}=\frac{v_{i, j}}{U_{i}}$

Stage1:

$\alpha_{i}^{1}=\frac{\widehat{v_{l}}}{\sum_{j} v_{i j}^{0}} \rightarrow v_{i j}^{1}=\alpha_{i}^{1} v_{i j}^{0} \rightarrow \beta_{j}^{1}=\frac{\widehat{v_{e j}}}{\sum_{i} v_{i j}^{1}} \rightarrow v_{i j}^{2}=\beta_{i}^{1} v_{i j}^{1}$ 
Stage2:

$\alpha_{i}^{2}=\frac{\widehat{v_{h}}}{\sum_{j} v_{i j}^{2}} \rightarrow v_{i j}^{3}=\alpha_{i}^{2} v_{i j}^{2} \rightarrow \beta_{j}^{2}=\frac{\widehat{v_{\iota j}}}{\sum_{i} v_{i j}^{3}} \rightarrow v_{i j}^{4}=\beta_{i}^{2} v_{i j}^{3}$

Stage 3:

$\alpha_{i}^{m}=\frac{\widehat{v_{\mathrm{l}}}}{\sum_{j} v_{i j}^{2 m-2}} \rightarrow v_{i j}^{2 m-1}=\alpha_{i}^{m} v_{i j}^{2 m-2} \rightarrow \beta_{j}^{m}=\frac{\widehat{v_{j}}}{\sum_{i} v_{i j}^{2 m-1}} \rightarrow v_{i j}^{2 m}=\beta_{i}^{m} v_{i j}^{2 m-1}$

The iterations can be summarized as:

$v_{i j}^{2 m-1}=\left(\prod_{p=1}^{m} \alpha_{i}^{p}\right)\left(\prod_{q}^{m-1} \beta_{j}^{q}\right) v_{i j}^{0} ;$ for odd rank value, $v_{i j}^{1} v_{i j,}^{3} v_{i j_{2}}^{5} \ldots$

$v_{i j}^{2 m}=\left(\prod_{p=1}^{m} \alpha_{i}^{p}\right)\left(\prod_{q}^{m} \beta_{j}^{q}\right) v_{i j}^{0} ;$ for even rank value, $v_{i j,}^{2} v_{i j,}^{4} v_{i j}^{6} \ldots$

$A_{i}^{m}=\prod_{p=1}^{m} \alpha_{i}^{p}$ and $B_{j}^{m}=\prod_{q}^{m} \beta_{j}^{q}$

$v_{i j}^{2 m-1}=A_{i}^{m} B_{j}^{m-1} v_{i j}^{0}$

The odd rank is: $\quad v_{i j_{2}}^{1} v_{i j_{2}}^{3} v_{i j_{2}}^{5} \ldots$

$v_{i j}^{2 m}=A_{i}^{m} B_{j}^{m} v_{i j}^{0}$

The even rank is:

$v_{i j,}^{2} v_{i j,}^{4} v_{i j,}^{6} \ldots$

as:

$\min H=\sum_{i} \sum_{j} v_{i j}^{1} \ln \frac{v_{i j}^{1}}{v_{i j}^{0}}=\sum_{i} \sum_{j} v_{i j}^{1} \ln v_{i j}^{1}-\sum_{i} \sum_{j} v_{i j}^{1} \ln v_{i j}^{0}$

$\sum_{j} v_{i j}^{1} X_{j}=X_{i}, \sum_{j} v_{i j}^{1}=1$

$v_{i j}^{1}$ is a new value of cell $i j$ and $0 \leq v_{i j}^{1} \leq 1$

$\min H=\sum_{i} \sum_{j} g_{i j} \ln \frac{g_{i j}}{h_{i j}}$ 
Subject to: $\quad \sum_{i} g_{i j}=\widetilde{g_{v j}}, \Sigma_{j} g_{i j}=\widetilde{g_{l}}$

$g_{i j}$ are the adjusted matrix and $q_{i j}$ are the initial matrix

$g_{i j}=\frac{v_{i j}}{\sum_{m} \Sigma_{n} v_{m n}}, h_{i j}=\frac{v_{i j}^{0}}{\sum_{m} \sum_{n} v_{m n}^{0}}$

The Lagrangian Solution:

$\Delta=\sum_{i} \sum_{j} g_{i j} \ln \frac{g_{i j}}{h_{i j}}+\sum_{i} \alpha_{i}\left(\sum_{j} g_{i j}-\widetilde{g_{h}}\right)+\sum_{j} \beta_{j}\left(\sum_{i} g_{i j}-\widetilde{g_{s j}}\right)$

The first-order conditions are:

$\frac{\partial \Delta}{\partial \alpha_{i}}=\sum_{j} g_{i j}-\widetilde{g_{l .}}, \frac{\partial \Delta}{\partial \beta_{j}}=\sum_{i} g_{i j}-\widetilde{g_{s j}}, \frac{\partial \Delta}{\partial g_{i j}}=1+\ln g_{i j}-\ln h_{i j}+\alpha_{i}+\beta_{j}=0$

$g_{i j}=h_{i j} e^{-\left(1+\alpha_{i}+\beta_{j}\right)}$

Where $\alpha_{i}$ and $\beta_{j}$ are Lagrangian multipliers.

\section{RESULTS OF SAM ANALYSIS FOR MCCURTAIN COUNTY}

This section discusses and analyzes the results of the SAM for McCurtain's economy. The overall objective is to estimate the economic effects of Broken Bow Lake on McCurtain County, including the distribution of the effects among residents of the county.

Broken Bow Lake represents a fixed resource for McCurtain County. Returns to this resource arise because of the activity outputs (purposes) of the project. Outputs of hydroelectric power and municipal and industrial water activities are valued at market prices. Output of the flood control activity is equal to losses prevented and assumed equal to net income. Value of output of recreation is on the basis of a net benefit per visitor day. This is a non-market transaction and estimated using information from recreation studies.

Because the U. S. Army Corps of Engineers' budget is from the national treasury, thus not an allocated cost against the Broken Bow Lake project activities, the entire value of project activities can be attributed to the Broken Bow Lake factor account. For this reason, the market value of hydro-electric power of $\$ 5,717,000$ and the market value of municipal and industrial water of $\$ 88,000$ are allocated as factor payments to Broken Bow Lake. This does not mean that there is an actual transaction of this amount to Broken Bow Lake, but rather, it represents a return to society because of the public project. Some payments to the national treasury do actually occur because of contractual arrangements made for power generation and municipal water.

Visitor day net benefits for the Broken Bow Lake recreation activity are estimated using data from Cannock. Average net benefits per visitor day for lakes Tenkiller and Fort Gibson were estimated by Cannock at $\$ 1.25$ in 1999 prices. In 2000 prices the estimated benefit is $\$ 2.24$. Assuming equal benefit per visitor day at Broken Bow Lake as existed for lakes Tenkiller and Fort Gibson, the estimated net benefits for 1,033,000 visitor days are equal to $\$ 2,313,920$. This is the value recorded as a payment to the Broken Bow Lake factor account.

Because these benefits accrue to recreationists (consumer surplus), the distribution of these benefits are assumed equal to the distribution of visitor days. Thus the distribution would be as follows in Table 2. 
Table 2

\begin{tabular}{lcc}
\hline & Institution & Recreation Visitor Day Benefits (\$) \\
\hline Households & 36,329 \\
Low Income & 59,352 \\
Medium Income & 20,015 \\
High Income & $\mathbf{1 1 5 , 6 9 6}$ \\
Subtotal & $2,198,224$ \\
Exogenous (exports) & $\mathbf{2 , 3 1 3 , 9 2 0}$ \\
TOTAL & \\
\hline
\end{tabular}

A summary of the distributions of Broken Bow Lake factor payments, by project purpose, to the household accounts and the exogenous account is as follows $(\$ 1,000)$ in Table 3.

Table 3

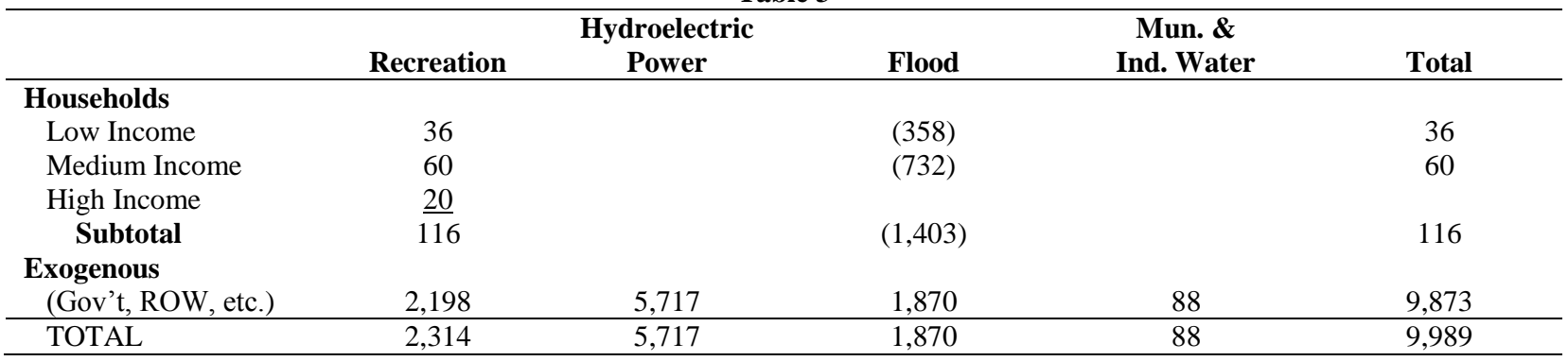

The results above should be interpreted carefully because they do not necessarily measure actual transactions that occur within the McCurtain County economy. The total Broken Bow Lake factor payments are estimated to be $\$ 9,989,000$ and include both market and nonmarket transactions. Recreation net benefits of $\$ 2,314,000$ are a nonmarket transaction and are distributed among households within McCurtain County and households outside of McCurtain County. The distributions to households are added to household incomes, thus the total households' distributions indicate market and nonmarket values.

Hydroelectric power benefits are valued at market prices for electricity and therefore represent opportunity costs of electricity purchased from alternative sources. Part of the value is captured through contracts with electric cooperatives. Flood control represents losses prevented. The data above indicate which households receive the losses prevented, but are not added to the household rows because the incomes are already valued through other factors and thus included in county incomes. The figures, therefore, are shown in ( ) to avoid double counting. Municipal and industrial water is valued at market prices and, thus, is handled in the same way as hydroelectric power.

\section{INTERDEPENDENCE COEFFICIENTS WITH BROKEN BOW LAKE IDENTIFIED}

The Interdependence coefficients for the McCurtain County SAM with Broken Bow Lake identified have the following interpretation. For a $\$ 1,000$ change in the Agriculture activity, the direct and indirect change or total change in agriculture is $\$ 1,077$. For the same change in Agriculture, the direct and indirect change in the Services activity is $\$ 100$.

The demand for Agricultural commodities from McCurtain County will change by $\$ 76.70$, Mining and Manufacturing commodities by $\$ 8.20$, and Services commodities by $\$ 104.60$. Employee Compensation will change by $\$ 92.80$. Proprietary Income by $\$ 70.10$, Property Income by $\$ 55$, Indirect Business Tax by $\$ 22.40$, and returns to Broken Bow Lake by $\$ 1.10$. Income of Low Income Households will change by $\$ 47.60$, Medium Income Households by $\$ 77.50$, and High Income Households by $\$ 25.70$. The total McCurtain County income effect will be the sum of the Households effect or $\$ 150.80$. 
Exogenous changes in the Activities account, however, have little meaning other than to show the interdependence of the production activities with the rest of the economy. The exogenous account for Activities contains only minor entries indicating that the importance of the Activities account is in the deliveries to the Commodities account.

Interpretation of the Agricultural commodities has more significance. For a $\$ 1,000$ change in Agricultural commodities, presumably for export out of the county, the total change in the Agricultural activity will be $\$ 1,071$, for Mining and Manufacturing activity $\$ 10.50$, and for Services activity $\$ 99.70$. Similarly, the total change in Agricultural commodities will be $\$ 1,076$ of which $\$ 1,000$ will be exported and $\$ 76$ will be used by other endogenous accounts in McCurtain County.

Total demand for other commodities is interpreted from the inter-dependence coefficients of the Agricultural commodities. Similarly, the interdependence coefficients for the Agricultural commodities and the factor payments and the households give the respective changes in factor payments and household incomes.

The interdependence coefficients of the Broken Bow Lake activities and commodities have similar interpretations; however, some of the accounts were defined in physical units rather than monetary units. For example, for a 1,000 change in visitor days of the Recreation activity, the Mining and Manufacturing activity will change by $\$ 2.20$, the Services activity will change by $\$ 7.50$, the Hydroelectric Power activity will change by 1 $\mathrm{KWH}$, and the U.S. Army Corps of Engineers activity will change by $\$ 10.70$. Employee Compensation in the factor accounts will change by $\$ 2.60$ and the Broken Bow Lake factor account will change by $\$ 2,240$. Household income in the aggregate will change by $\$ 28.80$.

The interdependence coefficients form the basis for estimating the impact Broken Bow Lake has on the economy of McCurtain County. The next section presents the impact results of Broken Bow Lake on McCurtain County.

\section{THE ESTIMATED IMPACTS OF BROKEN BOW LAKE ON MCCURTAIN COUNTY}

The impacts of Broken Bow Lake on the McCurtain County economy are estimated in two parts. The first part is the estimated impact of the exogenous changes in the commodities account associated with the functions of Broken Bow Lake. The second part is the estimated impact of the Broken Bow Lake on the endogenous accounts such as the effects of McCurtain County residents participating in recreation activities. Finally, the sum of the impacts of Broken Bow Lake on household income is compared with total household income for the County. Table 4.

The exogenous commodity accounts associated with functions of the Broken Bow Lake are summarized in

Table 4: Exogenous Commodity Accounts (Exports) Associated with Broken Bow Lake

\begin{tabular}{|c|c|c|c|c|c|}
\hline & Commodity & Recreation & (Hydroelectric Power) & (Flood Control) & Total \\
\hline (1) & Agriculture (\$) & 96,959 & & & 96,959 \\
\hline (2) & Forestry (\$) & 62,681 & & & 62,681 \\
\hline (3) & Min. \& Manuf (\$) & $3,076,256$ & & & $3,076,256$ \\
\hline (4) & Transportation (\$) & 131,238 & & & 131,238 \\
\hline (5) & Trade $(\$)$ & $2,298,622$ & & & $2,298,622$ \\
\hline (6) & Services $(\$)$ & 840,314 & $5,430,914$ & & $6,271,228$ \\
\hline (7) & Recreation (VD) & 981,000 & & & 981,000 \\
\hline (8) & $\begin{array}{l}\text { Hydroelectric Power } \\
(1,000 \mathrm{kwh})\end{array}$ & & 181,030 & & 181030 \\
\hline (9) & Flood Control (\$) & & & 467,500 & 467,500 \\
\hline
\end{tabular}

The endogenous effects of Broken Bow Lake are associated with household consumption of commodities produced by the Lake functions and by increased household incomes from losses avoided through flood control. Table 5 represents the endogenous effects: 
Table 5: Exogenous Commodity Accounts (Households) Associated with Broken Bow Lake

\begin{tabular}{|c|c|c|c|c|c|c|}
\hline & Commodities & Recreation & $\begin{array}{c}\text { (Hydroelectric } \\
\text { Power) }\end{array}$ & $\begin{array}{c}\text { (Flood } \\
\text { Control) }\end{array}$ & $\begin{array}{c}\text { Municipal } \\
\text { Water }\end{array}$ & Total \\
\hline (1) & Agriculture (\$) & 5,103 & & & & 5,103 \\
\hline (2) & Forestry $(\$)$ & 3,300 & & & & 3,300 \\
\hline (3) & Min \& Manuf. (\$) & 161,908 & & & & 161,908 \\
\hline (4) & Transportation (\$) & 6,907 & & & & 6,907 \\
\hline (5) & Trade $(\$)$ & 120,980 & & & & 120,980 \\
\hline (6) & Services $(\$)$ & 44,227 & 285,838 & & 87,600 & 417,665 \\
\hline (7) & Recreation (VD) & 52,000 & & & & 52,000 \\
\hline \multirow[t]{3}{*}{ (8) } & Hydroelectric & & & & & \\
\hline & Power & & & & & \\
\hline & $(1,000 \mathrm{kwh})$ & & 9,528 & & & 9,528 \\
\hline (9) & Flood Control (\$) & & & $4,402,501$ & & $1,402,501$ \\
\hline \multirow[t]{5}{*}{ (10) } & Mun. \& Ind. Water (mg) & & & & 1,095 & 1,095 \\
\hline & Households & & & & & \\
\hline & Low Income (\$) & & & 357,638 & & 357,638 \\
\hline & Medium Income (\$) & & & 732,105 & & 732,105 \\
\hline & High Income (\$) & & & 312,758 & & 312,758 \\
\hline
\end{tabular}

The impact of Broken Bow Lake can now be estimated for any of the endogenous accounts by multiplying the above Commodity Accounts by the appropriate interdependence coefficients. Income for Low Income Households associated with the exogenous commodity account for Broken Bow Lake (exports of recreation, hydroelectric power, and flood control) is estimated at $\$ 1,284,000$. In Table 6, income for Medium Income Households is $\$ 2,146,000$ and income for High Income Households is $\$ 745,000$. Total McCurtain County household income associated with the exogenous commodity account is $\$ 4,175,000$.

Table 6: Impact Of Broken Bow Lake Exogenous Commodity Account On McCurtain County Household Income By Income Class Size

\begin{tabular}{|c|c|c|c|c|c|}
\hline & \multirow[b]{2}{*}{ Commodity } & \multirow[b]{2}{*}{$\begin{array}{c}\text { Exogenous } \\
\text { Commodity Account }\end{array}$} & \multicolumn{3}{|c|}{$\begin{array}{c}\text { Household Income } \\
\text { Interdependence Coefficient }\end{array}$} \\
\hline & & & Low Income & $\begin{array}{c}\text { Medium } \\
\text { Income }\end{array}$ & High Income \\
\hline \multicolumn{6}{|c|}{ Activities } \\
\hline (1) & Agriculture (\$) & 96,959 & 0.0474 & 0.0773 & 0.0256 \\
\hline (2) & Forestry $(\$)$ & 62,681 & 0.0774 & 0.1395 & 0.0545 \\
\hline (3) & Mining \& Manuf. (\$) & $3,076,256$ & 0.1009 & 0.1627 & 0.0529 \\
\hline (4) & Transportation $(\$)$ & 131,238 & 0.1420 & 0.2298 & 0.0753 \\
\hline (5) & Trade $(\$)$ & $2,298,622$ & 0.1490 & 0.2390 & 0.0770 \\
\hline (6) & Services $(\$)$ & $6,271,228$ & 0.0944 & 0.1645 & 0.0612 \\
\hline (7) & Recreation (VD) & 981,000 & 0.0089 & 0.0149 & 0.0050 \\
\hline (8) & $\begin{array}{l}\text { Hydroelectric Power } \\
(1,000 \mathrm{kwh})\end{array}$ & 181,030 & 0.0001 & 0.0002 & 0.0001 \\
\hline (9) & Flood Control (\$) & 467,500 & 0.0039 & 0.0066 & 0.0022 \\
\hline \multicolumn{6}{|c|}{ Total Income } \\
\hline $\operatorname{Imp}$ & $000)$ & & 1,284 & 2,146 & 745 \\
\hline
\end{tabular}


Table 7: Impact Of Broken Bow Lake Exogenous Commodity And Household Accounts On McCurtain County Household Income By Income Class Size

\begin{tabular}{|c|c|c|c|c|c|}
\hline & \multirow[b]{2}{*}{ Commodity } & \multirow[b]{2}{*}{$\begin{array}{l}\text { Endogenous } \\
\text { Account }\end{array}$} & \multicolumn{3}{|c|}{$\begin{array}{c}\text { Household Income } \\
\text { Interdependence Coefficient }\end{array}$} \\
\hline & & & Low Income & $\begin{array}{l}\text { Medium } \\
\text { Income }\end{array}$ & High Income \\
\hline \multicolumn{6}{|c|}{ Activities } \\
\hline (1) & Agriculture (\$) & 5,103 & 0.0474 & 0.0773 & 0.0256 \\
\hline (2) & Forestry $(\$)$ & 3,300 & 0.0774 & 0.1395 & 0.0545 \\
\hline (3) & Mining \& Manuf. (\$) & 161,908 & 0.1009 & 0.1627 & 0.0529 \\
\hline (4) & Transportation (\$) & 6,907 & 0.1420 & 0.2298 & 0.0753 \\
\hline (5) & Trade $(\$)$ & 120,980 & 0.1490 & 0.2390 & 0.0770 \\
\hline (6) & Services $(\$)$ & 417,665 & 0.0944 & 0.1645 & 0.0612 \\
\hline (7) & Recreation (VD) & 52,000 & 0.0089 & 0.0149 & 0.0050 \\
\hline (8) & $\begin{array}{l}\text { Hydroelectric Power } \\
(1,000 \mathrm{kwh})\end{array}$ & 9,528 & 0.0001 & 0.0002 & 0.0001 \\
\hline (9) & Flood Control (\$) & $1,402,501$ & 0.0039 & 0.0066 & 0.0022 \\
\hline (10) & Mun. \& Indus. Water (mg) & 1,095 & 0.0006 & 0.0009 & 0.0003 \\
\hline \multicolumn{6}{|c|}{ Households } \\
\hline (1) & Low Income (\$) & 357,638 & 1.0207 & 0.0357 & 0.0131 \\
\hline (2) & Medium Income (\$) & 732,105 & 0.0213 & 1,0368 & 0.0134 \\
\hline (3) & High Income (\$) & 312,758 & 0.0245 & 0.0420 & 1.0152 \\
\hline \multicolumn{6}{|c|}{ TOTAL INCOME } \\
\hline Impact & & & 470 & 921 & 380 \\
\hline
\end{tabular}

Table 7 shows that income for Low Income Households is estimated at \$470,000; for Medium Income Households, it is \$921,000, and for High Income Households, it is \$380,000. The majority of this income impact is due to losses prevented from flood control, which is a direct increase in income of households. The total McCurtain County household income associated with the endogenous commodity and household income accounts is $\$ 1,771,000$.

In Table 8, income impact of Broken Bow Lake is compared with total McCurtain County income. The income impact associated with the exogenous commodity accounts is $\$ 4,175,000$, or about 1.56 percent of total McCurtain County income. The income impact associated with the endogenous accounts is $\$ 1,771,000$, or about 0.66 percent. The total income impact of Broken Bow Lake is \$5,946,000, or about 2.22 percent of McCurtain County income. This compares with Agriculture direct factor payments of $\$ 8,988,000$, or about 3.36 percent of McCurtain County income. Applying the household interdependence coefficients to aggregate agricultural activity, output $(\$ 55,811,000)$ shows the total household income interdependence with agriculture of $\$ 8,418,000$, or about 3.1 percent. The distribution of the income impact by household income class size shows that Broken Bow Lake accounts for the smallest share for Low Income Households (2.09 percent) and the highest share for High Income Households (2.42 percent). The differences among household income class sizes are because of differences in participation of households in employee compensation, proprietary income, and property income. Broken Bow Lake impacts apparently are marginally associated with factor returns more beneficial to the higher income household. 
Table 8: Income Impact From Broken Bow Lake Compared To Total McCurtain County Income By Income Class Size

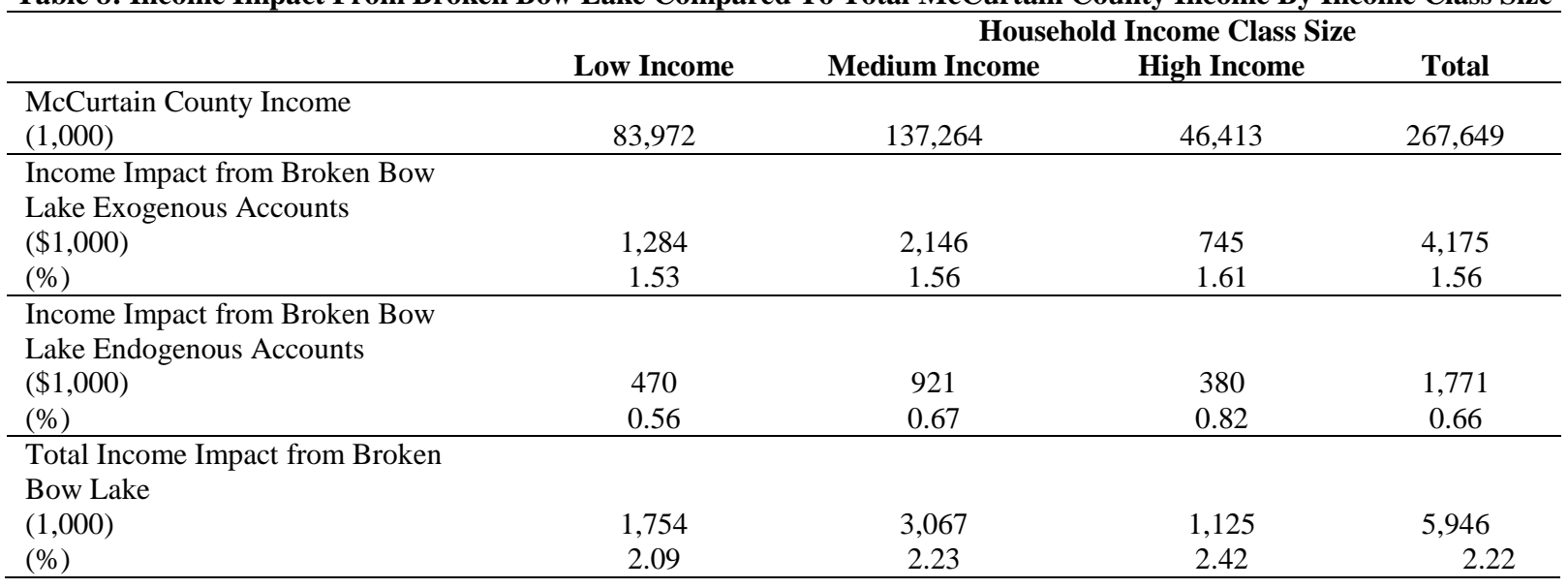

\section{SUMMARY AND CONCLUSIONS}

The disaggregated SAM shows the activities, commodities, factor payments and households in greater detail. One result is that if the exogenous account for medium income household changes by $\$ 1,000$, e.g., as a result of changes in the tax laws, those households will have a total direct and indirect income change of $\$ 1,036.70$. The low income households will reflect an increase of $\$ 1,035.70$. The high income households will change by slightly more, for a total effect of $\$ 1,041.90$. Income distribution implications are suggested by such analyses.

The third and most detailed disaggregation shows the impact of the project purposes of the Broken Bow Lake. These purposes are recreation, hydro-power, flood control, and municipal and industrial water supply. The U. S. Army Corps of Engineers is included as their continuing presence coordinates the four project purposes. Data from previous studies supplies the estimates of per-dollar distribution of recreation expenditures for commodities and households. Medium income households "spent" the most visitor days and "consumed" the most visitor days, with low income households second in importance, and high income households the least on both expenditures and consumption.

Corps of Engineers project personnel estimates that 95 percent of the hydroelectric power is consumed outside of McCurtain County. Consequently, the local impact is low.

Benefits from flood control represent flood losses avoided. It is assumed this loss represents net additions to income. This income flows primarily to agriculture for a total of $\$ 1,420,501$. Municipal and industrial water has a relatively small impact from use within McCurtain County. The annual value of all water used locally is $\$ 87,600$. The U. S. Army Corps of Engineers' budget is from the National treasury and thus not allocated against Broken Bow Lake. Their operating budget is their aggregate expenditure of $\$ 197,000$.

Exogenous changes in the activities account have minor impact. Exogenous changes in the commodities account are more significant. For example, a $\$ 1,000$ change in employee compensation, as a result of changes in the minimum wage, would impact most heavily on services and mining and manufacturing. A $\$ 1,000$ change in the Broken Bow Lake factor payments will change medium income households by $\$ 6.40$, low income by $\$ 3.90$, and high income by $\$ 2.20$. A change in visitor days by 1,000 will change medium income households by $\$ 14.90$, low income by $\$ 8.90$, and high income by $\$ 5.00$.

Hydroelectric power, mining and manufacturing and trade are the major exogenous commodity changes due to Broken Bow Lake. The total McCurtain County household income associated with the exogenous commodity account is $\$ 4,175,000$. The majority of this income impact is due to losses from flood control. The distribution of the income impact shows that Broken Bow Lake accounts for the smallest share for low income households (2.09 percent) and the highest share for high income households (2.42 percent). 
The major impact of Broken Bow Lake on McCurtain County is the increase in recreation available to local residents, flood protection and the modest income brought to local residents by the non-local tourists. The benefits comprise a higher share of the income for high income households than they do for the income of low income households. The major impact outside the County is the generation of hydroelectric power and municipal and industrial water. The dollar amounts of external benefits are much larger than the benefits within McCurtain County. McCurtain County has not been successful in capturing these major benefits from the Broken Bow Lake project.

\section{POLICY IMPLICATIONS}

An investment, such as Broken Bow Lake, generates substantial income. The income generated locally is largely income from recreation. Without additional local investment in farm and other businesses to capitalize on the hydroelectric power, flood control, municipal and industrial water, and possibly irrigation, the capacity of these multiple purpose investments to generate local income is limited. The bulk of the income generated will flow outside the local area.

Without additional investment, the middle income households capture the largest proportion of the income generated. This serves to reduce the income gap between middle and high income households. It also widens the gap between low and middle income households. Additional investment should be directed to low income household if reduction of income disparity is considered as one part of government policy.

The multiple purpose investment at Broken Bow Lake also increases the quality of life, in that local households send money to the broken bow project. Having no user's fees for most of the recreation actives makes this quality of life improvement more accessible to low income households. The biggest household expenditures go to hydroelectric power. However, the area was electrified prior to Broken Bow Lake. The benefits of this aspect of Broken Bow Lake project flow outside the immediate County. Local investment to utilize the newly created electrical generating capacity is an example of a policy that could retain, in McCurtain, a larger proportion of the wealth created by the investment in Broken Bow Lake.

Unlike an input-output matrix, the Social Accounting Matrix (SAM) allows the benefits of government investments to be traced to those people who benefit from the investment. These beneficiaries can be grouped by geographic, household income, or other characteristics. This allows the government to estimate the impact of its investments on its regional development and/or social welfare policies. A SAM is therefore an essential exercise in the planning and selection of government investments. Social accounting matrices should be constructed quite early in the planning process to develop those projects most compatible with the government's social policies. Once an investment is selected, a detailed SAM can help discover impediments to full participation in the benefits by all local inhabitants. However, the Social Accounting Matrix has some limitations. This model is demand driven and completely ignores issues of price adjustments, resource allocation, productivity and factor utilization. The model, with its fixed coefficients, ignores substitution possibilities in consumption, production, imports and exports triggered by changes in relative prices. The model does not capture the behavior of economic agents interacting across markets in response to shifts in price signals. Finally, the results, conclusion, and policy recommendation of this study are limited by the accuracy of the data and the assumption of fixed price multiplier. An improvement on the limitations might be accomplished by incorporating optimizing behavior in the description of the behavior of the various institutions in the SAM and by allowing the production and demand functions to be more flexible. This is left for further research.

\section{AUTHOR INFORMATION}

G. Solomon Osho is an Associate Professor at Prairie View A \& M University-The Texas A\&M University. He teaches Applied Statistical Techniques at both undergraduate and graduate levels. He has authored and coauthored articles in refereed journals and two books in the field of statistical applications.

Emmanuel I.S. Ajuzie, Lincoln University of Missouri, Jefferson city, Mo 65102. He is an Associate Professor, working as research and extension economist and teaches economics for Business and managerial statistics at undergraduate and graduate levels. He has authored and co-authored articles and abstracts in refereed journals. 
Matthew Uwakonye is a Full Professor of economics at Grambling State University and teaches economics and statistics. He has authored and co-authored several articles in refereed journals and conference proceedings in various areas of economics and econometrics. He is the Larry Lundy Endowed Professor of Business at the college of Business of Grambling State University Louisiana.

\section{REFERENCES}

1. Alward, Greg, Eric Siverts, Doug Olson, John Wagner, Dave Senf and Scott Lindall. Micro IMPLAN Software Manual (October 9-13, 1989).

2. Alward, G., H. Davis, K. Despotakis, and E. Lofting, 1985. "Regional Non-Survey Input-Output Analysis with IMPLAN.” Paper presented at the Southern Regional Science Association Conference, Washington, D.C.

3. Badger, Daniel D. "Economic Impacts of Selected Water Uses: Agriculture, Recreation, and Flood Control," presented at Symposium on Waters of Mid-America: Present Demands and Future Development, sponsored by American Institute of Biological Sciences and held in conjunction with $30^{\text {th }}$ Annual Meeting of AIBS, Stillwater, Oklahoma, August 15, Professional Paper P-731 of the Oklahoma Agricultural Experiment Station.

4. Badger, Daniel D., Dean F. Schreiner and Ronald W. Presley. Analysis of Expenditures for Outdoor Recreation at the McClellan-Kerr Arkansas River Navigation System. Publication prepared under Contract No. DACW 31-74-C-0161, Water Resources, Fort Belvoir, Virginia, IWR Contract Report 77-4, December 1977.

5. Bureau of Economic Analysis. Regional Economic Information System, 1982-1987. 1988.

6. Cabbiness, Siney G. and Daniel D. Badger. "Economic Impact of Recreation Businesses in Counties Along the Arkansas River Navigation System," presented at the Annual Meeting of the Southern Agricultural Economics Association, Atlanta, Georgia, February 3, 1981. Professional paper P-905 of the Oklahoma Agricultural Experiment Station.

7. Cannock, G. M., 1988. "Analysis of Water-based Recreation Markets for Two Competing Lakes in the McClellan-Kerr Arkansas River Navigation System Under Alternative Government Policies.”

8. Chang, James D. and Daniel D. Badger. "The Impact of Water Transport on the Oklahoma Economy," presented at Annual Meeting fo the American Agricultural Economics Association, Virginia Polytechnic Institute and State University, Blacksburg, Virginia, August 6-9, 1978. Journal Article 3505 of the Oklahoma Agricultural Experiment Station.

9. Davis, K. J. de Melo and S. Robinson. "General Equillibrium Models for Development Policy." Cambridge University Press. 1982.

10. Hazell, P. B. R., and A. Roell, 1983. Rural Growth Linkages: Household Expenditure Patterns in Malaysia and Nigeria. Washington, D.C.: International Food Policy and Research Institute.

11. Leontief, Wassily W. The Structure of American Economy, $1919-19392^{\text {nd }}$ ed. New York: Oxford University Press, 1951.

12. Maki, Wilbur R., Con H. Schallau, Bennett B. Foster, and Clair H. Redmond. Oklahoma's Forest Product Industry: Performance and Contribution to the State's Economy. 1970-1980. Oklahoma State University, Stillwater, Oklahoma.

13. McCathy, F. J. and Taylor, 1977. Macro Food Policy Planning: A General Equilibrium Model for Pakistan. MIT International Nutrition Planning Program, Cambridge, MA.

14. Napitupulu, Togar Alam, 1989. Structural Adjustment to Exchange Rate Policy in a General Equillibrium Framework: The Case of Indonesia.

15. Newman, Phillip C. Arthur D. Gayer, and Milton H. Spencer. Source Readings in Economic Thought. New York: W. W. Norton and Company, 1965.

16. Oglesby, Eliza S., 1973. History of McCurtain County.

17. Pyatt, G. and R. A. roe, 1977. "Social Accounting for Development Planning, With Special Reference to Sri Lanka." Cambridge University Press.

18. Richardson, H. W. 1972. Input-Output and Regional Economics. John Wiley and Sons, New York.

19. Robinson, Sherman, and David W. Roland-Hoist. "Modeling Structural Adjustment in the U. S. Economy: Macroeconomics in a Social Accounting Framework, (April 1987). 
20. Schreiner, Dean F., Dolores A. Willett, Daniel D. Badger and L. George Antle. "Recreation Benefits Measured by Travel Cost Method for the McClellan-Kerr Arkansas River Navigation System and Application to Other Selected Corps Lakes." Contract Report 85-C-1, U. S. Army Corps of Engineers, Water Resources Support Center, For Belvoir, Virgina, February 1985.

21. Schreiner, Dean F., Pirom P. Chantaworn, and Daniel D. Badger. Investment Planning for Multiple Purpose Uses of Wter Resource Projects in Oklahoma. Bulletin B-784, Oklahoma State University, Agricultural Experiment Station, Stillwater, Oklahoma, March 1987.

22. Shoven, John B. and John Whalley, 1984. "Applied General Equilibrium Models of Taxation and International Trade." Journal of Economics Literature, Vol. 22, No. 3, (September), pp. 1007-1051.

23. Stone, J.R.N., 1966. "The Social Accounts From a Consumer Point of View." Review of Income and Wealth, Series 12, No. 1, pp. 1-33.

24. Stone, J.R.N. "The Disaggregation of the Household Sector in the National Accounts." Social Accounting Matrices: A Basis for Planning, ed. G. Pyatt and J. I. Round. Washington, D.C.: World Bank, 1985.

25. U. S. Army Corps of Engineers. Water Resources Development in Oklahoma, 1985. Published by Southwestern Division, Corps of Engineers, Dallas, Texas.

26. Warner, Larkin, Daniel D. Badger, and Gerald Lage. The Economic Impact of Tenkiller Ferry Lake. Published by Research Foundation, Oklahoma State University. Publication prepared for U.S. Army Corps of Engineers, Tulsa District, August 1973. 


\section{NOTES}

